\title{
PERLINDUNGAN HUKUM PEMILIK SERTIPIKAT HAK ATAS TANAH DALAM HAL TERJADI KESALAHAN DATA PENERBITANNYA (Studi Kasus Di Kantor Pertanahan Kota Semarang)
}

\author{
Andina Alfia Rizqi, Yusriyadi \\ Fakultas Hukum, Universitas Diponegoro \\ J1. Prof. Soedarto, SH. Tembalang, Semarang 50275 \\ email : andinarizqi@gmail.com
}

\begin{abstract}
This article is about legal protection for certificate owners in regard to registration error. The error might cause loss of land ownership of related certificate. This research used socio legal approach and descriptive specification analysis. The results of the study revealed that physical and juridical data error in land registration caused the certificate owner to suffer the loss of land ownership. The error also triggered a poor land administration system. Land registration guarantees legal land ownership. Thus, regarding errors on land certificate registration, BPN as the institution issuing the certificate makes corrections or revises the errors in Land Ownership Certificate.Based on the findings.
\end{abstract}

Keywords: Legal Protection, Certificate Registration Error.

\begin{abstract}
Abstrak
Penelitian ini mengenai Perlindungan hukum pemilik sertipikat dalam hal terjadi kesalahan data penerbitannya karena apabila hal ini terjadi maka mengakibatkan hilangnya unsur kepastian hukum hak atas tanah pada sertipikat yang bersangkutan. Penelitian ini mengambil lokasi di Kota Semarang. Adapun pendekatan yang digunakan adalah socio legal dan spesifikasi deskriptif analitis. Dari penelitian tersebut ditemukan bahwa kesalahan data fisik maupun data yuridis dalam pendaftaran tanah mengakibatkan hilangnya unsur kepastian hukum hak atas tanah, sehingga pemilik sertipikat dirugikan. Kesalahan ini juga akan menciptakan sistem administrasi pertanahan yang tidak tertib. Dengan terdaftarnya hak atas tanah memberikan jaminan keamanan kepemilikannya untuk mewujudkan kepastian hukum. Apabila terdapat kesalahan dalam data penerbitan sertipikat, bentuk perlindungan hukum yang diberikan oleh BPN sebagai pihak yang mengeluarkan sertipikat yaitu dilakukan pembetulan atau revisi atas kesalahan di dalam sertipikat Hak Atas Tanah.
\end{abstract}

Kata Kunci: Perlindungan Hukum, Kesalahan Penerbitan Sertipikat.

\section{A. Pendahuluan}

Dalam rangka menjamin kepastian hak dan kepastian hukum atas tanah, Undang-Undang Pokok Agraria (UUPA) Nomor 5 tahun 1960 telah menggariskan adanya keharusan untuk melaksanakan pendaftaran tanah diseluruh Indonesia. Untuk menunjang perkembangan Hukum Tanah Nasional dimana hukum adat merupakan sumber utamanya dan sesuai dengan ketentuan 
Pasal 19 ayat (1) dan ayat (2) Undang-Undang Nomor 5 Tahun 1960 tentang Peraturan Dasar Pokok-Pokok Agraria (UUPA) yang berbunyi:

"Untuk menjamin kepastian hukum oleh Pemerintah diadakan Pendaftaran Tanah di seluruh wilayah Republik Indonesia menurut ketentuan-ketentuan yang diatur dengan Peraturan Pemerintah. Pendaftaran tersebut meliputi: a) Pengukuran, pemetaan dan pembukuan tanah; b)Pendaftaran hak-hak atas tanah dan peralihan hak-hak tersebut; c) Pemberian surat-surat tanda bukti hak yang berlaku sebagai alat pembuktian yang kuat.”

Menurut Boedi Harsono, pendaftaran tanah adalah rangkaian kegiatan yang dilakukan oleh pemerintah secara terus menerus, berkesinambungan dan teratur, meliputi pengumpulan, pengolahan, pembukuan dan penyajian serta pemeliharaan data fisik dan data yuridis, dalam bentuk peta dan daftar mengenai bidang-bidang tanah dan satuan-satuan rumah susun, termasuk pemberian sertipikat sebagai surat tanda bukti haknya bagi bidang-bidang tanah yang sudah ada haknya dan Hak Milik Atas Satuan Rumah Susun serta hak-hak tertentu yang membebaninya.(Harsono, 1990)

Di Indonesia setiap hak atas tanah, hak pengelolaan, tanah wakaf dan hak milik atas satuan rumah susun didaftar dengan membukukannya dalam buku tanah, yang memuat data fisik dan data yuridis bidang tanah yang bersangkutan dan sepanjang ada surat ukurnya, yang dicatat pula pada surat ukur tersebut. Pembukuan dalam buku tanah serta pencatatannya pada surat ukur merupakan bukti bahwa hak yang bersangkutan serta pemegang haknya dan bidang tanahnya yang diuraikan dalam surat ukur secara hukum telah didaftar menurut Peraturan Pemerintah Nomor 24 tahun 1997 (vide Pasal 29 PP Nomor 24 Tahun 1997). Selanjutnya menurut Pasal 31 PP Nomor 24 Tahun 1997 dinyatakan bahwa untuk kepentingan pemegang hak yang bersangkutan diterbitkan sertipikat sesuai dengan data fisik yang ada dalam surat ukur dan data yuridis dalam buku tanah.(Harsono, 2002)

Tujuan pendaftaran tanah sebagaimana diatur dalam UUPA dan PP Nomor 24 Tahun 1997 adalah untuk memberikan kepastian hukum dan perlindungan hukum kepada pemegang hak atas tanah. Kepastian dan perlindungan hukum tersebut dibuktikan dengan adanya alat bukti yang dihasilkan dari pendaftaran tanah yang berupa Buku Tanah dan Sertipikat Tanah yang terdiri atas Salinan Buku Tanah dan Surat Ukur.

Setelah diterbitkannya sertipikat hak atas tanah oleh instansi terkait, dalam hal ini adalah Badan Pertanahan Nasional, tidak menjamin pihak yang namanya tercantum dalam sertipikat 
tidak dapat digugat oleh pihak lain yang merasa memiliki hak atas tanah yang sama. Hal ini karena sistem pendaftaran tanah yang dianut oleh UUPA adalah sistem pendaftaran negatif yaitu dimana bagi pihak lain yang merasa mempunyai hak yang lebih kuat dengan disertai bukti-bukti yang dimilikinya dapat mengajukan gugatan ke Pengadilan. Apabila pembuktian tersebut dapat dibuktikan maka sertipikat yang telah diterbitkan dapat dibatalkan. Sertipikat hak atas tanah merupakan tanda bukti yang mutlak. Artinya apabila terdapat kekeliruan dalam sertipikat tersebut maka masih dimungkinkan untuk dikoreksi melalui pembatalan(Hartanto, 2014).

Selain itu pada saat pengurusan sertipikat ternyata masih banyak sertipikat yang mengandung kesalahan penerbitan baik kesalahan prosedur, kesalahan ukur, kesalahan dalam penerapan peraturan perundang-undangan, kesalahan pencantuman subyek hak, kesalahan obyek haknya, kesalahan jenis hak, kesalahan perhitungan luas tanah, kesalahan tumpang tindih hak, kesalahan data fisik dan yuridis, dan kesalahan administrasi lainnya seperti yang tercantum dalam Pasal 107 Peraturan Menteri Agraria/Kepala BPN Nomor 9 Tahun 1999.

Bagi pemegang hak, sertipikat yang mengandung kesalahan dalam penerbitan sertipikat seharusnya diberikan perlindungan hukum sebagaimana maksud undang-undang mengenai pendaftaran tanah yaitu jaminan kepastian hukum hak atas tanah sehingga dapat merugikan pemegang hak tersebut. Pemegang sertipikat yang terjadi kesalahan dalam penerbitannya memiliki implikasi tidak saja terhadap pemegang hak yang beritikad baik dalam memperoleh tanah tersebut, tetapi juga bagi pihak ketiga atau pihak yang akan berkepentingan baik terhadap tanah yang bersangkutan. Untuk menanggulangi timbulnya kesalahan dalam penerbitan sertipikat perlu adanya upaya aktif dan peran serta dari segenap lapisan masyarakat serta instansi yang terkait dengan bidang pertanahan seperti Notaris/Pejabat Pembuat Akta Tanah (PPAT), Kantor Badan Pertanahan Nasional, serta peranan penegak hukum atau badan peradilan.

Berdasarkan uraian dalam latar belakang tersebut, maka dalam penulisan ini akan mengkaji mengenai masalah Bagaimana akibat hukum bagi pemilik sertipikat Hak Atas Tanah apabila terjadi kesalahan data penerbitan sertipikatnya dan Mengapa Pemerintah perlu memberikan perlindungan hukum bagi pemilik sertipikat Hak Atas Tanah terjadi kesalahan dalam data penerbitan sertipikatnya serta bagaimana bentuk perlindungan hukumnya

\section{B. Metode Penelitian}

Metode pendekatan yang digunakan dalam penelitian ini adalah socio-legal research. Metode socio legal research merupakan pemeriksaan yang mendalam terhadap fakta sosial 
untuk kemudian mengusahakan suatu pemecahan atas permasalahan yang timbul dalam gejala yang bersangkutan(Marzuki, 2008). Dalam penelitian ini, penulis akan melakukan penelitian mengenai perlindungan hukum pemilik sertipikat Hak Atas Tanah dalam hal terjadi kesalahan dalam data penerbitan sertipikat dan akibat hukum yang ditimbulkan apabila terjadi kesalahan dalam data penerbitan sertipikat. Hal ini bertujuan untuk melihat praktek dalam masyarakat saat ini, masih banyak yang terkena kesalahan tersebut atau tidak, kemudian penulis berusaha untuk mencari solusi atas permasalahan tersebut.Penulis akan melakukan penelitian dalam hal ini terhadap masyarakat pemegang sertipikat yang merasa dirugikan atas kesalahan dalam data penerbitan sertipikat tersebut. Spesifikasi yang digunakan dalam penelitian ini bersifat deskriptif analitis yang bertujuan menggambarkan secara tepat sifat-sifat suatu individu, keadaan gejala, atau kelompok tertentu, atau untuk menentukan penyebaran suatu gejala, atau untuk menentukan ada atau tidaknya hubungan antara suatu gejala dengan gejala lain dalam masyarakat(Amirudiin; \& Asikin, 2004). Deskriptif Analitis menggambarkan peraturan perundang-undangan yang berlaku yang dikaitkan dengan teori-teori hukum dan praktek pelaksanaan hukum positif yang menyangkut permasalahan di atas(Soemitro, 1998).

Penelitian ini menggambarkan das sollen dan das sein mengenai perlindungan hukum bagi pemilik sertipikat dalam hal terjadi kesalahan data penerbitannya yang mana seharusnya hal tersebut tidak terjadi, karena pemerintah harus memberikan perlindungan hukum yang semestinya agar terjaminnya kepastian hukum pemilik sertipikat, namun senyatanya terjadi adalah masih banyak sertipikat yang terjadi kesalahan dalam data penerbitannya di Kantor Pertanahan Kota Semarang. Berdasarkan hal tersebut terdapat kesenjangan antara das sollen dan das sein sehingga penelitian ini akan mengkaji dan menganalisis dengan menggunakan teoriteori hukum.

Data penelitian ini diperoleh dari berbagai sumber seperti Kantor Pertanahan Kota Semarang dan Pemilik Sertipikat yang terjadi kesalahan data penerbitannya, sedangkan jenis data yang digunakan dalam penelitian ini meliputi Data Primer yang diperoleh dengan cara mengadakan penelitian lapangan dengan mengadakan wawancara. Data sekunder diperoleh dari penelitian kepustakaan sebagai bahan pelengkap yang berkaitan dengan teori-teori yang ada.

Dalam penelitian ini analisis data yang digunakan adalah analisis yang bersifat kualitatif. Teknik analisis data yang bersifat kualitatif yang artinya menguraikan data secara bermutu dalam kalimat yang teratur, runtun, logis, tidak tumpang tindih, dan efektif sehingga memudahkan inpretasi data dan pemahaman hasil analisis(Muhammad, 2004). Penelitian kualitatif adalah 
penelitian tentang riset yang bersifat deskripsi dan cenderung menggunakan analisis dengan pendekatan induktif.Induktif merupakan suatu cara penelitian yang berangkat dari fakta-fakta yang ditemukan di lapangan kemudian di analisis dengan konsep teori yang digunakan dalam penelitian(Sudarman, 2002). Penelitian ini fokus tehadap perlindungan hukum pemilik sertipikat dalam hal terjadi kesalahan data penerbitannya dan menemukan solusi atas kesalahan tersebut agar terjaminnya kepastian hukum.

\section{Hasil dan Pembahasan}

\section{Akibat Hukum Kesalahan dalam Penerbitan Sertipikat Hak Atas Tanah}

Sertipikat hak atas tanah adalah suatu produk Pejabat Tata Usaha Negara (TUN), sehingga atas berlakunya ketentuan-ketentuan Hukum Administrasi Negara. Atas perbuatan hukum tersebut seseorang selaku pejabat TUN dapat saja melakukan perbuatan-perbuatan yang terlingkup sebagai perbuatan yang melawan hukum baik karena kesalahan (schuld) maupun akibat kelalaian menjalankan kewajiban hukumnya.

Atas perbuatan yang salah atau lalai tadi menghasilkan produk hukum sertipikat yang salah, baik kesalahan atas subjek hukum dalam sertipikat maupun kesalahan atas objek hukum dalam sertipikat tersebut. Kesalahan mana telah ditenggarai dapat terjadi dalam berbagai proses pendaftaran tanah.

Kesalahan dalam pembuatan sertipikat bisa saja karena adanya unsur penipuan (bedrog), kesesatan (dwaling) dan/ atau paksaan (dwang), dalam buku tanah. Dengan demikian sertipikat yang dihasilkan dapat berakibat batal demi hukum. Adapun bagi subyek yang melakukan hal tersebut dapat dikatakan telah melakukan perbuatan melawan hukum (onrechtmatigedaad). Apabila perbuatan dilakukan oleh alat-alat perlengkapan negara/BPN, maka perbuatan tersebut dapat dikategorikan sebagai onrechtmatige overheidsdaad atau penyalahgunaan kewenangan dari Pejabat Tata Usaha Negara(Kalo, 2007).

Perbuatan hukum Pemerintah / BPN dalam melakukan pendaftaran tanah dan menerbitkan sertipikat sebagai perbuatan hukum untuk menimbulkan keadaan hukum baru dan melahirkan hak-hak serta kewajiban-kewajiban hukum baru terhadap orang atau subyek hukum tertentu harus memenuhi syarat-syarat dan tidak boleh mengandung unsur kesalahan baik menyangkut aspek teknis pendaftaran tanah maupun aspek yuridis. Pasal 52 UUPA telah mengamanatkan penegakan hukum dan bidang pendaftaran tanah dapat dikenakan sanksi pidana atas perbuatanperbuatan tertentu. Peraturan pelaksanaan dari ketentuan ini dirumuskan dalam Pasal 42 sampai dengan Pasal 44 Peraturan Pemerintah Nomor 10 Tahun 1961. Kebijakan kriminalisasi dalam PP 
10/1961 dengan tegas menentukan bahwa sanksi pidana terhadap pelanggaran batas-batas dari suatu bidang tanah dinyatakan dengan tanda-tanda batas menurut ketentuan yang ditetapkan oleh Menteri Agraria.

Kesalahan data fisik maupun data yuridis dalam pendaftaran tanah akan mengakibatkan hilangnya unsur kepastian hukum hak atas tanah, sehingga orang yang berhak terhadap tanah tersebut akan dirugikan. Kesalahan juga akan berakibat terjadinya informasi yang salah di BPN sebagai alat kelengkapan negara yang akibatnya juga berarti menciptakan administrasi pertanahan yang tidak tertib.

Badan Pertanahan Nasional menurut teori Pasrons mengandung dua pengertian utama yaitu Pertama, merupakan suatu kesatuan dari beberapa sub-sistem pendaftaran tanah atau elemen definisi pada sistem pendaftaran tanah yang menekankan pada komponen atau elemennya, Kedua, merupakan suatu prosedur birokrasi secara umum yaitu untuk mencapai tujuan definisi birokrasi yang menekankan prosedur. Sistem pendaftaran tanah yang menerangkan bahwa sistem birokrasi adalah komponen-komponen atau subsistem-subsistem pendaftaran tanah yang saling berinteraksi, dimana masing-masing bagian tersebut dapat bekerja secara sendiri-sendiri (independent) atau bersama-sama serta saling berhubungan membentuk satu kesatuan sehingga tujuan atau sasaran sistem pendaftaran tanah tersebut dapat tercapai secara keseluruhan. Sistem pendaftaran tanah yang menekankan pada prosedurnya menerangkan bahwa sistem pendaftaran tanah adalah suatu jaringan kerja dari prosedur-prosedur birokrasi yang saling berhubungan, berkumpul bersama untuk melakukan suatu kegiatan atau untuk menyelesaikan suatu sasaran tertentu. Teori ini adalah lukisan abstraksi yang sistematis mengenai keperluan sosial (kebutuhan fungsional) tertentu, yang mana setiap masyarakat termasuk birokrat harus memeliharanya untuk memungkinkan pemeliharaan kehidupan sosial yang stabil(Widhi, 2014).

Penerbitan sertipikat hak atas tanah sebagai hasil akhir proses pendaftaran tanah termasuk perubahan-perubahan menyangkut subjek, status hak dan perbuatan-perbuatan hukum yang dilakukan terhadap tanahnya merupakan alat pembuktian yang kuat. Hal ini berarti bahwa keterangan-keterangan yang tercantum di dalamnya mempunyai kekuatan hukum yang harus diterima sebagai keterangan yang benar selama dan sepanjang tidak ada alat pembuktian yang membuktikan sebaliknya. Apabila ternyata dalam pendaftaran tanah ada data yang tidak benar, maka akan diadakan perubahan dan pembetulan atas kesalahan tersebut. Pembetulan tersebut dilakukan langsung oleh Badan Pertanahan Nasional (BPN) seperti yang dinyatakan oleh Mahmud (Sub Seksi Pendaftaran Tanah Kantor Pertanahan Kota Semarang) bahwa: 
"Ya apabila ada pembetulan karena kesalahan dari kami ya pasti kami betulkan kesalahan tersebut, mau bagaimanapun itu adalah produk kami, jadi kami yang harus bertanggungjawab atas kesalahan tersebut."

Atas pernyataan tersebut, maka apabila terjadi kesalahan data penerbitan sertipikat, jika tidak dilakukan pembetulan atau revisi sertipikat yang bersangkutan maka akan menimbulkan akibat tidak terjaminnya kepastian hukum atas sertipikat karena sertipikat merupakan alat pembuktian yang kuat.

\section{Perlindungan Hukum Terhadap Pemilik Sertipikat Hak Atas Tanah}

Pendaftaran tanah menurut Peraturan Pemerintah Nomor 24 Tahun 1997 menggunakan sistem Publikasi Negatif. Dengan diterapkannya sistem ini memberikan pengaruh yang besar dalam sistem pendaftaran tanah di Indonesia. Dalam sistem ini negara hanya secara pasif menerima apa yang dinyatakan oleh pihak yang meminta pendaftaran. Oleh karena itu sewaktuwaktu dapat digugat oleh orang yang merasa lebih berhak atas tanah itu. Pihak yang memperoleh tanah dari orang yang sudah terdaftar tidak dijamin. Walaupun dia memperoleh tanah itu dengan itikad baik. Hal ini berarti dalam sistem publikasi negatif keterangan-keterangan yang tercantum di dalamnya mempunyai kekuatan hukum dan harus diterima sebagai keterangan yang benar selama dan sepanjang tidak ada alat pembuktian yang membuktikan sebaliknya(Sutedi, 2011).

Sistem publikasi dalam penyelenggaraan pendaftaran tanah mempermasalahkan sejauh mana orang boleh mempercayai kebenaran data yang disajikan oleh Negara sebagai hasil kegiatan pendaftaran tanah yang dilaksanakan. Dan apa akibat hukumnya jika orang dalam melakukan perbuatan hukum dengan tanah yang sudah terdaftar itu menggunakan data tersebut dan kemudian ternyata data itu terbukti tidak benar(Harsono, 2002).

Kebaikan dari sistem negatif adalah: a) adanya perlindungan pada pemegang hak yang sebenarnya; b) adanya penyelidikan riwayat tanah sebelum sertipikat diterbitkan. Dalam sistem pendaftaran negatif, bagi pejabat pendaftaran tanah tidak ada keharusan untuk memeriksa atas nama siapa pendaftaran haknya. Pejabat pendaftaran tanah mendaftarkan hak-hak dalam daftardaftar umum atas nama pemohonnya tanpa mengadakan pemeriksaan terlebih dahulu terhadap pemohonnya, sehingga pekerjaan pendaftaran peralihan hak dalam sistem negatif dapat dilakukan secara cepat dan lancar, sebagai akibat tidak ditiadakannya pemeriksaan oleh pejabat pendaftaran tanah. Adapun kelemahan dalam sistem negatif adalah tidak terjaminnya kebenaran dari isi daftar-daftar umum sebagai pemegang hak harus menangkal sendiri resikonya jika yang terdaftar itu ternyata bukan pemegang hak yang sebenarnya(Sutedi, 2011). 
Stelsel negatif memang telah memunculkan dampak terhadap kepastian hukum itu sendiri. Pemegang hak atas tanah yang dapat membuktikan bukti-bukti yang sah akan dilindungi oleh hukum yang berlaku. Jangkauan kekuatan pembuktian setipikat yang dinyatakan sebagai alat pembuktian yang kuat oleh UUPA diberikan dengan syarat selama belum dibuktikan yang sebaliknya, data fisik dan data yuridis yang dicantumkan dalam sertipikat harus diterima sebagai data yang benar, baik dalam perbuatan hukum sehari-hari maupun dalam sengketa pengadilan, sepanjang data tersebut sesuai dengan apa yang tercantum dalam surat ukur dan buku tanah yang bersangkutan, dan orang tidak dapat menuntut tanah yang sudah bersertipikat atas nama orang atau badan hukum lain, jika selama 5 (lima) tahun sejak dikeluarkannya sertipikat itu orang yang merasa memiliki tanah tidak mengajukan gugatan pada pengadilan, sedangkan tanah tersebut diperoleh orang atau badan hukum lain tersebut dengan itikad baik dan secara fisik nyata dikuasai olehnya atau orang lain atau oleh badan hukum yang mendapat persetujuannya.

Asas itikad baik memberikan perlindungan kepada orang yang dengan itikad baik memperoleh suatu hak dari orang yang disangka sebagai pemegang hak yang sah. Sedangkan dalam asas hukum nemo plus yuris, seseorang tidak dapat melakukan tindakan hukum yang melampaui hak yang dimilikinya, dan akibat dari pelanggaran tersebut batal demi hukum (van rechtswegenietig), yang berakibat perbuatan hukum tersebut dianggap tidak pernah ada dan karenanya tidak mempunyai akibat hukum dan apabila tindakan hukum tersebut menimbulkan kerugian, maka pihak yang dirugikan tersebut dapat meminta ganti rugi kepada pihak-pihak yang melakukan perbuatan hukum tersebut. Asas nemo plus yuris memberikan perlindungan hukum kepada pemegang hak yang sebenarnya terhadap tindakan pihak lain yang mengalihkan haknya tanpa sepengetahuannya. Oleh karena itu, asas nemo plus yuris selalu terbuka kemungkinan adanya gugatan kepada pemilik yang namanya tercantum dalam sertipikat dari orang yang merasa sebagai pemiliknya.Berdasarkan asas nemo plus yuris, maka penguasaan sesuatu hak atas tanah oleh orang yang tidak berhak adalah batal. Dengan demikian pemegang hak yang sebenarnya selalu dapat menuntut kembali haknya yang telah dialihkan tanpa sepengetahuannya dari siapa pun hak itu berada. Hal ini sangat penting untuk memberi perlindungan kepada pemegang hak atas tanah yang sebenarnya. Umumnya asas ini berlaku dalam sistem pendaftaran tanah negatif.

Begitupun dengan asas aman, dimaksudkan untuk menunjukkan bahwa pendaftaran tanah perlu diselenggarakan secara teliti dan cermat sehingga hasilnya dapat memberikan jaminan kepastian hukum sesuai tujuan pendaftaran tanah itu sendiri. Makna aman pada dasarnya lebih 
mengacu pada suatu akibat dari perbuatan subyek hukum, akan tetapi bukan mengacu pada hasil atau obyek hukum dari dilaksanakan pendaftaran tanah tersebut. Adanya asas aman ini memberikan perlindungan bagi pemegang sertipikat tanah untuk merasa aman dan nyaman dengan diberikannya jaminan kepastian hukum dari Kantor Pertanahan.

Di dalam penjelasan PP Nomor 24 Tahun 1997 ditegaskan bahwa dalam pendaftaran tanah, sistem publikasinya adalah sistem negatif, tetapi yang mengandung unsur positif, karena akan menghasilkan surat-surat tanda bukti hak yang berlaku sebagai alat pembuktian yang kuat. Stelsel positif dituangkan di dalam hal-hal berikut:

a. PPAT diberikan tugas untuk meneliti secara materiil dokumen-dokumen yang diserahkan dan berhak untuk menolak pembuatan akta;

b. Kantor Pertanahan Kabupaten/Kotamadya berhak menolak melakukan pendaftaran jika pemilik tidak mempunyai wewenang mengalihkan haknya.

Penggunaan ciri-ciri stelsel positif dapat menutupi kelemahan-kelemahan stelsel negatif. Bagi masyarakat yang masih perlu mendapat bimbingan hal ini merupakan bantuan yang besar untuk mencegah terjadinya hal-hal yang dapat menimbulkan kerugian pada pemilik yang sebenarnya dan para pembeli. Dengan demikian makna pernyataan bahwa sertipikat merupakan alat pembuktian yang kuat dan bahwa tujuan pendaftaran tanah diselenggarakan untuk memberikan jaminan kepastian hukum di bidang pertanahan menjadi tampak dirasakan arti praktisnya, sungguh pun sistem publikasi yang digunakan adalah sistem negatif. Sistem publikasi tersebut tidak mengurangi rasa pemberian perlindungan yang seimbang baik kepada pihak yang mempunyai tanah maupun kepada pihak yang memperoleh dan menguasainya dengan itikad baik dan dikuatkan dengan sertipikat tanah(Sutedi, 2011).

Menurut Widhi Handoko, Penggunaan stelsel publisitas negatif (berunsur positif) menunjukan konsep perlindungan hukum terhadap pemegang Hak Atas Tanah terabaikan, hal mana dapat dilihat dari tidak adanya pertanggungjawaban terhadap hasil produk sertipikat Hak Atas Tanah. Pertanggungjawaban yang terdapat pada stelsel publisitas negatif yaitu pada pejabat ambtenaar. Beralihnya stelsel publisitas negatif menjadi stelsel publisitas negatif (berunsur positif) ini belum memenuhi unsur penerapan dan pelaksanaan hukum. Konsep perlindungan hukum terhadap pemegang Hak Atas Tanah tidak dapat dilepaskan dengan persoalan keadilan dalam pelaksanaan hukum itu sendiri. Gustav Radburch mengemukakan ada tiga nilai dasar yang ingin dikejar dan perlu mendapatkan perhatian serius dari para pelaksana hukum yaitu nilai keadilan hukum, kepastian hukum dan kemanfaatan hukum, sehingga dengan pilihan stelsel 
publisitas negatif (berunsur positif) tersebut maka tiga nilai dasar itu sendiri tidak mungkin tercapai.

Tujuan kebijakan hukum pertanahan pada stelsel publisitas negatif (berunsur positif) terkait erat dengan tujuan sistem hukum pertanahan itu sendiri yaitu terciptanya masyarakat adil, makmur dan sejahtera, oleh karena itu pilihan penggunaan sistem hukum pertanahan pada stelsel publisistas negatif (berunsur positif) mestinya berorientasi pada nilai-nilai dasar hukum yaitu untuk mewujudkan ketertiban dan keteraturan, kedamaian serta keadilan. Oleh Soediman Kartohadiprodjo diberikan istilah Pengayoman (Perlindungan)(Widhi, 2014).

Walaupun pendaftaran tanah menganut sistem publikasi negatif, petugas pendaftaran tanah dalam melakukan tugasnya harus melakukan penelitian, pemeriksaan dan monitoring mengenai batas tanah, letak tanah, luas tanah, status tanah, keadaan tanah apakah dalam keadaan sengketa atau tidak dan sebagainya. Disamping itu petugas pendaftaran tanah juga diharuskan untuk mengumumkan dalam waktu yang ditentukan menurut Peraturan Pemerintah No. 24 Tahun 1997 untuk memberi kesempatan pada semua pihak yang merasa keberatan. Dengan diterapkannya sistem publisitas negatif tersebut maka apabila ada kesalahan penerbitan sertipikat hak atas tanah dapat diberikan perlindungan hukum yang memberikan pengayoman bagi pemilik atau pemegang sertipikat hak atas tanah tersebut. Pejabat/ instansi yang berwenang dapat melakukan tindakan yang dilakukan agar kesalahan tersebut tidak merugikan pemegang sertipikat yang bersangkutan atau pihak ketiga.

Di dalam usaha untuk menyediakan data fisik dan data yuridis yang benar, kegiatan pendaftaran tanah untuk pertama kali dalam PP No. 24 Tahun 1997 dan peraturan pelaksanaannya diatur secara sangat rinci. Mulai dari tahap pengumpulan sampai pengumuman untuk memberi kesempatan kepada siapapun mengajukan keberatan, diikuti dengan pembuatan surat ukurnya dan pembukuannya dalam buku tanah serta penerbitan sertipikatnya. Sertipikat baru diterbitkan apabila semua data sudah lengkap dan tidak ada lagi yang disengketakan. Demikian juga pengaturan pencatatan perubahan-perubahannya yang terjadi kemudian pada tahap pemeliharaan data.

Sudah barang tentu dalam usaha menyediakan data yang benar, dan usaha untuk memberikan perlindungan hukum bagi pemilik sertipikat selain kelengkapan pengaturannya, tidak kurang pentingnya tingkat penguasaan ketentuan pengaturannya oleh para pejabat pelaksana kegiatan pendaftaran. Demikian juga tingkat ketelitian dan kemampuan dalam menilai kebenaran data yang diperlukan sebagai dasar pendaftaran, mulai pada tahap pengumpulan data 
sampai penerbitan sertipikatnya, terutama oleh para pelaksana di lapangan. Sebagaimana dimaklumi dalam kegiatan pendaftaran untuk pertama kali sumber datanya hampir semua tidak tertulis, karena mengenai bidang-bidang tanah adat yang perolehan serta peralihan haknya jarang berdokumen lengkap. Pengaturan ini juga berlaku pada tahap pemeliharaan data, bilamana terjadi perubahan. Sebagai pejabat pelaksana pendaftaran pada tahap pemeliharaan data termasuk Pejabat Pembuat Akta Tanah (PPAT), yang bertugas dan berwenang membuat akta-akta tanah tertentu(Harsono, 2002).

Perlindungan hukum yang diberikan apabila terjadi kesalahan dalam penerbitan sertipikat yang diberikan oleh Kantor Pertanahan khususnya Kota Semarang adalah dengan cara dilakukan pembetulan atas kesalahan tersebut. Pembetulan tersebut bisa dilakukan kapan saja. Pembetulan ini juga tidak dikenakan biaya apapun juga kesalahan yang terjadi hanya pada kesalahan penulisannya saja, tetapi akan dikenakan biaya yang dinamakan Penerimaan Negara Bukan Pajak (PNBP) apabila kesalahan tersebut pada surat ukur, kesalahan luas ataupun kesalahan batas, sehingga harus dilakukan pengukuran ulang. Pembetulan ini dilakukan oleh pemohonnya langsung, Pembetulan ini biasa dinamakan Revisi Sertipikat. Alur permohonan revisi sertipikat yang telah penulis teliti adalah:

a. Pemohon secara langsung memberikan surat permohonan revisi yang dibuatnya sendiri dan dibubuhkan tanda tangannya.

b. Setelah surat masuk ke Kantor Pertanahan, maka akan di proses dan dilihat dahulu apa kesalahan yang telah dilakukan tersebut.

c. Dari pihak Kantor Pertanahan nantinya akan mengecek di dalam warkah dan melihat apakah benar terjadi kesalahan tersebut dari pihak internal Kantor Pertanahan atau dari pihak luar (Pemohon).

d. Jika memang kesalahannya dari Kantor Pertanahan maka akan dilakukan pembetulan kesalahan tersebut.

e. Pembetulan dari kesalahan tersebut dibubuhkan pada sertipikat dengan diberikan paraf sebagai tanda pembetulan oleh Kepala Kantor Pertanahan atau diwakilkan oleh Kepala Seksi di bidang pembetulan tersebut.

f. Setelah dilakukan pembetulan, sertipikat diberikan kepada pemiliknya.

Apabila ada kesalahan dalam penerbitan sertipikat yang benar-benar melanggar administrasi atau biasa disebut dengan Cacat Hukum Administrasi yaitu sertipikat Hak Atas Tanah yang terjadi kesalahan prosedur, kesalahan penerapan peraturan perundang-undangan, 
kesalahan subyek hak, kesalahan obyek hak, kesalahan jenis hak, kesalahan perhitungan luas, terdapat tumpang tindih hak atas tanah, data yuridis atau data fisik tidak benar atau kesalahan lainnya yang bersifat administratif yang termuat dalam Pasal 107 Peraturan Menteri Agraria/ Kepala Badan Pertanahan Nasional Nomor 9 Tahun 1999, maka jika seseorang pemilik sertipikat tersebut tetap bertahan atau tidak mau di revisi dan dibetulkan oleh Kantor Pertanahan maka dilakukan pembatalan sertipikat hak atas tanah, sedangkan apabila ada pihak lain yang merasa dirugikan dengan penerbitan sertipikat tersebut maka dapat diajukan gugatan permohonan pembatalan hak atas tanah melalui Peradilan Tata Usaha Negara.

Perangkat Hukum Tanah Nasional yang ada sekarang perlu dilengkapi dan diadakan penyempurnaan ketentuan dan rumusan lembaga-lembaga dan peraturan-peraturannya agar tersedia perangkat hukum yang secara lengkap dan jelas memuat ketentuan-ketentuan hukum yang dapat menghindarkan penafsiran yang keliru dalam pelaksanaannya. Dengan demikian benar-benar akan dapat diciptakan kepastian hukum dan diberikan perlindungan hukum yang seimbang kepada semua pihak dalam pelaksanaan pembangunan dan kehidupan sehari-hari, yang memerlukan penyediaan dan penguasaan tanah. Pelaksanaan pembangunan yang diharapkan benar-benar didasarkan pada kebijakan baru, yang kembali kepada semangat kebangsaan, kerakyatan, kebersamaan dan keadilan dari UUPA. Itulah sebabnya maka penyelenggaraan pendaftaran tanah menurut Peraturan Pemerintah Nomor 10 Tahun 1961 yang telah disempurnakan menjadi Peraturan Pemerintah Nomor 24 Tahun 1997 tentang Pendaftaran tanah harus dilakukan dengan teliti. Hal mana dicerminkan oleh ketentuan di dalam pasal peraturan tersebut. Dengan demikian maka kekuatan yuridis sertipikat sebagai alat pembuktian yang kuat tidak hanya terletak pada ketentuan Pasal 19 Undang-Undang Pokok Agraria itu saja, melainkan juga terutama karena keterangan-keterangan yang terdapat di dalamnya benar-benar dapat dipercaya yaitu sebagai hasil pekerjaan petugas-petugas pendaftaran tanah di Kantor Pertanahan yang teliti(Prakoso \& Purwanto, 1985).

\section{Simpulan}

Sertipikat hak atas tanah adalah suatu produk Pejabat Tata Usaha Negara (TUN), dalam hal ini adalah Badan Pertanahan Nasional (BPN). Perbuatan hukum pemerintah/BPN dalam melakukan pendaftaran tanah dan menerbitkan sertipikat menimbulkan keadaan hukum dan melahirkan hak-hak serta kewajiban-kewajiban hukum terhadap orang atau subjek hukum tertentu yang harus memenuhi syarat-syarat dan tidak boleh mengandung unsur kesalahan baik menyangkut aspek teknis maupun aspek yuridis pendaftaran tanah. Kesalahan data dalam 
penerbitan sertipikat berakibat batal demi hukum atau dapat dibatalkan. Kesalahan data fisik maupun data yuridis dalam pendaftaran tanah akan mengakibatkan hilangnya unsur kepastian hukum hak atas tanah, sehingga orang yang berhak terhadap tanah tersebut akan dirugikan. Kesalahan juga akan berakibat terjadinya informasi yang salah di BPN sebagai alat kelengkapan negara yang akibatnya juga menciptakan administrasi pertanahan yang tidak tertib.

Alasan perlunya diberikan perlindungan hukum apabila terjadi kesalahan data penerbitan sertipikat adalah Agar Kepastian Hukum pemilik sertipikat terjamin, karena sertipikat merupakan alat pembuktian yang kuat sehingga atas kesalahan tersebut tidak menimbulkan penyalahgunaan oleh siapapun maupun pihak ketiga. Dengan terdaftarnya bagian tanah tersebut sebenarnya tidak semata-mata akan terwujudnya jaminan keamanan akan kepemilikannya dalam menuju kepastian hukum. Apabila terdapat kesalahan dalam penerbitan sertipikat, maka bentuk perlindungan hukum pihak Badan Pertanahan Nasional sebagai pihak yang mengeluarkan sertipikat adalah dengan dilakukannya pembetulan atau revisi atas kesalahan di dalam sertipikat Hak Atas Tanah tersebut.

\section{DAFTAR PUSTAKA}

Amirudiin;, \& Asikin, Z. (2004). Pengantar Metode Penelitian Hukum. Jakarta: Raja Grafindo. Harsono, B. (1990). Hukum Agraria Indonesia: Sejarah Pembentukan Undang-Undang Pokok Agraria, Isi dan Pelaksanaannya, Jilid I : Hukum Tanah Nasional. Jakarta: Djembatan.

Harsono, B. (2002). Menuju Penyempurnaan Hukum Tanah Nasional. Jakarta: Universitas Trisakti.

Hartanto, A. (2014). Hukum Pertanahan Karakteristik Jual Beli Tanah Yang Belum Terdaftar Hak Atas Tanahnya. Surabaya: LaksBang Justitia.

Kalo, S. (2007). Aspek dan Implikasi Hukum dalam Pendaftaran Tanah dan Penerbitan Sertifikat Hak-Hak Atas Tanah. In Pertemuan Koordinasi Teknis Kuasa Hukum Pemda untuk Penanganan Perkara di Peradilan (p. 15). Medan.

Marzuki, P. M. (2008). Penelitian Hukum. Jakarta: Kencana.

Muhammad, A. (2004). Hukum dan Penelitian Hukum. Bandung: Citra Adiya Bakti.

Prakoso, D., \& Purwanto, B. A. (1985). Eksistensi Prona Sebagai Pelaksanaan Mekanisme Fungsi Agraria. Jakarta: Ghalia Indonesia.

Soemitro, R. H. (1998). Metode Penelitian Hukum dan Jurimetri. Jakarta: Ghalia Indonesia.

Sudarman, D. (2002). Menjadi Peneliti Kualitatif. Bandung: Pustaka Setia.

Sutedi, A. (2011). Sertifikat Hak Atas Tanah. Jakarta: Sinar Grafika.

Widhi, H. (2014). Kebijakan Hukum Pertanahan Sebuah Refleksi Keadilan Hukum Progresif. Yogyakarta: Thafa Media. 